Revista Brasileira de Farmacognosia Brazilian Journal of Pharmacognosy 21(3): 456-464, May./Jun. 2011

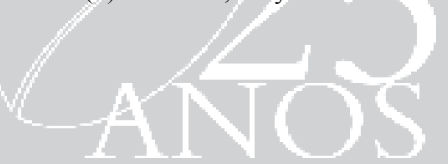

Article

Received 15 Apr 2010

Accepted 14 Nov 2010

Available online 15 Apr 2011

Keywords:

Brazilian Middle-west plants, cytotoxicity

cancer cell lines

ISSN 0102-695X

doi: $10.1590 / \mathrm{S} 0102-695 \mathrm{X} 2011005000061$

\section{In vitro cytotoxic activity of Brazilian Middle West plant extracts}

\author{
Talal Suleiman Mahmoud, ${ }^{*}, 1$ Maria Rita Marques, ${ }^{2}$ Cláudia do \\ Ó Pessoa, ${ }^{3}$ Leticia V. C. Lotufo, ${ }^{3}$ Hemerson I. F. Magalhães, ${ }^{3}$ \\ Manoel O. de Moraes, ${ }^{3}$ Dênis P. de Lima, ${ }^{4}$ Aristeu G. Tininis, ${ }^{5}$ \\ José Eduardo de Oliveira ${ }^{1}$
}

\author{
${ }^{1}$ Instituto de Química, Universidade Estadual Paulista, Brazil, \\ ${ }^{2}$ Laboratório de Bioquímica Vegetal, Fundação Universidade Federal do Mato Grosso \\ do Sul, Brazil, \\ ${ }^{3}$ Laboratório de Oncologia Experimental, Universidade Federal do Ceará, Brazil, \\ ${ }^{4}$ Departamento de Química-SINTMOLB-LP4, Fundação Universidade Federal do \\ Mato Grosso do Sul, Brazil, \\ ${ }^{5}$ Instituto Federal de Educação, Ciência e Tecnologia de São Paulo, Campus de \\ Sertãozinho, Brazil.
}

\begin{abstract}
Cytotoxic activity of eight plant extracts, native from the MidWest of Brazil comprising Cerrado, Pantanal and semideciduous forest, was evaluated for MDA-MB-435, SF-295, and HCT-8 cancer cell strains. A single $100 \mu \mathrm{g} . \mathrm{mL}^{-1}$ dose of each extract was employed with $72 \mathrm{~h}$ of incubation for all tests. Doxorubicin $\left(1 \mu \mathrm{g} \cdot \mathrm{mL}^{-1}\right)$ was used as the positive control and the MTT method was used to detect the activity. Cytotoxicity of distinct polarities was observed in thirty extracts (46\%), from different parts of the following species: Tabebuia heptaphylla (Vell.) Toledo, Bignoniaceae, Tapirira guianensis Aubl., Anacardiaceae, Myracrodruon urundeuva Allemão, Anacardiaceae, Schinus terebinthifolius Raddi, Anacardiaceae, Gomphrena elegans Mart., Amaranthaceae, Attalea phalerata Mart. ex Spreng., Arecaceae, Eugenia uniflora L., Myrtaceae, and Annona dioica A. St.-Hil., Annonaceae. Extracts of at least two tested cell strains were considered to be highly active since their inhibition rate was over $75 \%$.
\end{abstract}

\section{Introduction}

Brazil is one of the few megadiversity countries in the world but investigations of its flora have barely revealed the present phytochemical diversity. The newly discovered molecules have substantial scientific, economic and social interest. Furthermore, they may contribute to the development of interactive disciplines as well as show potential industrial uses for the improvement of health and the quality of life (Braz-Filho, 1999).

In order to carry out this work, the following plant species Tabebuia heptaphylla (Vell.) Toledo, Bignoniaceae, Tapirira guianensis Aubl., Anacardiaceae, Myracrodruon urundeuva Allemão, Anacardiaceae, Schinus terebinthifolius Raddi, Anacardiaceae, Gomphrena elegans Mart., Amaranthaceae, Attalea phalerata Mart. ex Spreng., Arecaceae, Eugenia uniflora L., Myrtaceae, and Annona dioica A. St.-Hil., Annonaceae, were selected. All species are native to the middle-west region of Brazil and are found in Cerrado, Pantanal and the semideciduous forest biomes in the state of Mato Grosso do Sul. Their selection was mainly based upon the use of these plants in traditional medicine.

People native to the Cerrado and Pantanal regions make use of a large variety of plants for medicinal purposes. A considerable part of their acquired knowledge was received from several indigenous ethnic groups living in this region far before the colonization of South America by the europeans (Maciel et al., 2002; Nunes et al., 2003).

\section{Material and Methods}

\section{Plant material and extraction procedure}

The vegetal material was collected in March 2007. The voucher specimen was deposited at the CGMS Herbarium of the Federal University of Mato Grosso do Sul-MS, Brazil. Gomphrena elegans Mart., Amaranthaceae, was collected in the Sucuri and Baía Bonita rivers in the Bonito district, the MS $\left(21^{\circ} 15^{\prime} 36.4^{\prime \prime} \mathrm{S}\right.$ 
and $56^{\circ} 32^{\prime} 58.1$ 'W) and voucher number CGMS 17715, Tabebuia heptaphylla (Vell.) Toledo, Bignoniaceae, voucher number CGMS 118999 and Attalea phalerata Mart. ex Spreng., Arecaceae, voucher number CGMS 24772 were collected in the Pantanal region, MirandaAbobral, subregion, around the Base of Studies of the Pantanal-UFMS (19³4'37'S and 5700'42'W), Tapirira guianensis Aubl., Anacardiaceae, voucher number CGMS 22907, Myracrodruon urundeuva Allemão, Anacardiaceae, voucher number CGMS 17659, Schinus terebinthifolius Raddi, Anacardiaceae, voucher number CGMS 22945, Annona dioica A. St.-Hil., Annonaceae, voucher number CGMS 17980 and Eugenia uniflora L., Myrtaceae, voucher number CGMS 25433 were collected in the Biological Reserve of the UFMS (20³0'25.5'S and 54o36'46”'W).

Leaves, stems bark and heartwood collection was performed in plants with natural injury. $100 \mathrm{~g}$ of each vegetal material (leaves and stems) was dried under air and cut into small pieces. They were crushed on Wiley type mill and the resulting matter was extracted with ethanol during seven days with occasional stirring, followed by the filtration and concentration of the filtrate by rotaevaporation. The filtrate was placed into desiccators for dehydration. Then, it was submitted to a process of liquid-liquid partition with solvents of increasing polarities: $n$-hexane, dichloromethane or chloroform, ethyl acetate, $n$-butanol or methanol and hydroalcohol or aqueous to obtain the respective fractions. All solvents were of analytical grade.

The choice of partition methods was based on pilot-experiments for each studied species, according to adapted methodology from Cechinel Filho \& Yunes (1998).

The following parts were submitted to a partition system with hexane, dichloromethane, ethyl acetate, butanol and hydroalcoholic: stem bark from Tabebuia heptaphylla; leaves and stem bark from Tapirira guianensis; stem bark of Myracrodruon urundeuva; leaves from Schinus terebinthifolius; leaves from Attalea phalerata; and leaves and stem from Gomphrena elegans. By this method, a residue containing more polar compounds, called polar fraction, is usually formed at the end of the partition process. Leaves, heartwood, stem bark, subterranean heartwood and subterranean stem bark from Annona dioica were submitted to partition system with hexane, chloroform, methanol and aqueous. In this method, the partition does not produce an insoluble residue. The crude extract of leaves from Eugenia uniflora and heartwood

Table 1. Vegetal extracts obtained for testing citotoxic activity against cell strains measured by the MTT assay.

\begin{tabular}{|c|c|c|c|c|c|c|c|c|c|}
\hline \multirow{2}{*}{ Species (part of the plant) } & \multirow{2}{*}{ Extracts $(\mathrm{g})$ Et } & \multicolumn{8}{|c|}{ Fractions (g) } \\
\hline & & $\mathrm{h}$ & $\mathrm{D}$ & $\mathrm{C}$ & $\mathrm{Ea}$ & $\mathrm{B}$ & $\mathrm{H}$ & M & A \\
\hline $\begin{array}{l}\text { Tabebuia heptaphylla (stem } \\
\text { bark) }\end{array}$ & - & 0.320 & 0.170 & - & 0.580 & 0.300 & 0.015 & - & - \\
\hline Tapirira guianensis (leaves) & 2.489 & 0.873 & 0.389 & - & 0.460 & 0.652 & 0.065 & - & - \\
\hline $\begin{array}{l}\text { Tapirira guianensis (stem } \\
\text { bark) }\end{array}$ & 1.470 & 0.260 & 0.114 & - & 0.470 & 0.735 & 0.211 & - & - \\
\hline $\begin{array}{l}\text { Myracrodruon urundeuva } \\
\text { (stem bark) }\end{array}$ & 1.760 & 0.330 & 0.387 & - & 0.354 & 0.609 & 0.030 & - & - \\
\hline $\begin{array}{l}\text { Myracrodruon urundeuva } \\
\text { (heartwood) }\end{array}$ & 0.954 & - & - & - & - & - & - & - & - \\
\hline $\begin{array}{l}\text { Schinus terebinthifolius } \\
\text { (leaves) }\end{array}$ & - & 0.630 & 0.743 & - & 0.840 & 0.517 & 0.110 & - & - \\
\hline Attalea phalerata (leaves) & - & 0.760 & 0.700 & - & 0,400 & 0.900 & 0.060 & - & - \\
\hline Eugenia uniflora (stem bark) & 0.420 & - & - & - & - & - & - & - & - \\
\hline Gomphrena elegans (leaves) & - & 0.090 & 0.110 & - & 0.034 & 0.380 & 0.256 & - & - \\
\hline Gomphrena elegans (stem) & - & 0.102 & 0.090 & - & 0.243 & 0.212 & 0.045 & - & - \\
\hline Annona dioica (leaves) & - & 0.870 & - & 0.670 & - & - & - & 0.850 & 0.097 \\
\hline Annona dioica (heartwood) & - & 0.434 & - & 0.320 & - & - & - & 0.680 & 0.045 \\
\hline Annona dioica (stem bark) & - & 0.643 & - & 0.576 & - & - & - & 0.345 & 0.064 \\
\hline $\begin{array}{l}\text { Annona dioica (heartwood } \\
\text { subterranean) }\end{array}$ & - & 0.123 & - & 0.280 & - & - & - & 0.290 & 0.023 \\
\hline $\begin{array}{l}\text { Annona dioica (stem bark } \\
\text { subterranean) }\end{array}$ & - & 0.230 & - & 0.245 & - & - & - & 0.310 & 0.033 \\
\hline
\end{tabular}

Solvents used in extraction: Et: ethanol, h: $n$-hexane, D: dichloromethane, C: chloroform, Ea: ethyl acetate, B: $n$-butanol, H: hydroalcohol, M: methanol, A: aqueous. 
of Myracrodruon urundeuva was not submitted to partition. Therefore, only the ethanol extract of this species was tested.

The extracts and fractions obtained from each plant, along with their weight, are shown in Table 1.

\section{Cytotoxicity studies}

The extracts cytotoxicity was tested against HCT-8 (human colon carcinoma), SF-295 (glioblastoma) and MDA-MB-435 (melanome) tumor cell strains (National Cancer Institute, Bethesda, MD, USA). Cells were cultured in RPMI-1640 medium, supplemented with $10 \%$ fetal calf serum, $2 \mathrm{mM}$ glutamine, 100 $\mu$ g.mL- 1 streptomycin and $100 \mathrm{U} . \mathrm{mL}^{-1}$ penicillin at 37 ${ }^{\circ} \mathrm{C}$ with $5 \% \mathrm{CO}_{2}$. For experiments, cells were plated in 96-well plates $\left(10^{5}\right.$ cells/well for adherent cells or $0.3 \times 106$ cells/well for suspended cells in $100 \mu \mathrm{L}$ of medium). After $24 \mathrm{~h}$, the extracts at $100 \mu \mathrm{g} \cdot \mathrm{mL}^{-1}$, or in serial dilution dissolved in DMSO (1\%) were added to each well and incubated for three days $(72 \mathrm{~h})$. Control groups received the same amount of DMSO. Doxorubicin (0.01-0.58 $\left.\mu \mathrm{g} . \mathrm{mL}^{-1}\right)$ was used as positive control. Growth of tumoral cells was quantified by the ability of living cells to reduce the yellow dye 3-(4,5dimethyl-2-thiazolyl)-2,5-diphenyl-2H-tetrazolium bromide (MTT) to a blue formazan product (Mosmann, 1983; Skehan et al., 1990; Berridge et al., 1996). At the end of $72 \mathrm{~h}$ incubation, the medium in each well was replaced by fresh medium $(200 \mu \mathrm{L})$ containing $0.5 \mathrm{mg} . \mathrm{mL}^{-1}$ of MTT. Three hours later, the formazan product of MTT reduction was dissolved in DMSO, and absorbance was measured using a multi-plate reader (DTX 880 Multimode Detector, Beckman Coulter Inc., Fullerton, CA, USA). Drug effect was quantified as the percentage of control absorbance of reduced dye at 590 nm (Zani et al., 1991; Da Silva et al., 2003; Correia et al., 2003). In our screening program to the discovery and development of potential anticancer natural compounds, we adopted the criteria of the American National Cancer Institute to consider a crude extract promising for further purification based on the IC50 values lower than $30 \mu \mathrm{g} . \mathrm{mL}^{-1}$ (Suffness \& Pezzuto, 1990).

In this context, we first assessed the extracts in a single concentration of $100 \mu \mathrm{g} \cdot \mathrm{mL}^{-1}$ to select those that inhibited cell growth in at least $75 \%$. The percentage of cell growth $(\% \mathrm{G})$ was calculated by comparing the absorbance of test samples with the control $(100 \%)$, zero-time $(0 \%)$ and the cytotoxic standard etoposide $(-100 \%)$. The percentage of cell lethality was obtained by the formula $[100 \times(\mathrm{T}-\mathrm{T} 0) /$ $(\mathrm{C}-\mathrm{T} 0)]$, where $\mathrm{T}=$ test, $\mathrm{T} 0=$ cell growth before addition of the extracts. The fractions were classified as possessing no activity (blank space), low activity (up to $50 \%$ growth inhibition), moderate activity (between $51 \%$ and $75 \%$ growth inhibition) and high activity (over 75\% growth inhibition) for each cell strain tested. Through this approach, the number of "false positive" extracts assessed were reduced.

The experiments were assessed according to the mean \pm SEM of percentage inhibition of cell growth using the Graphpad program (Intuitive Software for Scince, San Diego, CA).

\section{Results and Discussion}

The extracts activities are shown in Table 2. The tested cell strains were selected due to their resistance to different drugs. Samples were classified according to their cytotoxic potency as: no activity, low activity (growth inhibition ranging from 1 to $50 \%$ ), moderate activity (growth inhibition ranging from 51 to $75 \%$ ) and high activity (over $75 \%$ ).

All analyzed species showed cytotoxic activity. Among the 65 tested extracts from eight plant species, thirty showed considerable cytotoxicity, corresponding to $46 \%$ of all extracts as follows: Tabebuia heptaphylla (Vell.) Toledo, Bignoniaceae: dichloromethane, ethyl acetate and $n$-butanol of the stem bark; Tapirira guianensis Aubl., Anacardiaceae: all fractions of the leaves, with the exception of n-hexane; Tapirira guianensis: $n$-hexane and hydroalcohol of the stem bark; Myracroduon urundeuva Allemão, Anacardiaceae: ethyl acetate, $n$-butanol, hydroalcohol and ethanol of the stem bark; Myracroduon urundeuva: ethanol of heartwood; Schinus. terebinthifolius Raddi, Anacardiaceae: ethyl acetate of the leaves; Gomphrena elegans Mart., Amaranthaceae: $n$-hexane and $n$-butanol of the leaves; Attalea phalerata Mart. ex Spreng., Arecaceae: $n$-hexane, dichlorometane, ethyl acetate and hydroalcohol of leaves; Eugenia uniflora L., Myrtaceae: ethanol of stem bark; Annona dioica A. St.Hil., Annonaceae: $n$-hexane, chloroform, methanol and aqueous of the heartwood; Annona dioica: $n$-hexane, chloroform, methanol and aqueous of the Stem bark; Annona dioica: $n$-hexane, chloroform, methanol and aqueous of the heartwood subterranean; Annona dioica: $n$-hexane, chloroform, methanol and aqueous of the stem bark subterranean; Annona dioica: $n$-hexane, chloroform, methanol and aqueous of leaves, presented high cytotoxic activity (over 75\%).

By evaluating the families or the selected species one can clearly observe that they have medicinal properties.

The species Tabebuia heptaphylla is popularly known as "piúva" and is native to the Pantanal region. In traditional medicine, including indigenous people, the bark extract is used against cancer, as a stomach depurative and a bactericide 
Table 2. Cytotoxic activity of fractions from vegetal extracts against tumor cell lines measured by the MTT assay*.

\begin{tabular}{|c|c|c|c|}
\hline \multirow{2}{*}{ Sample } & \multicolumn{3}{|c|}{ *Lethality (\%) } \\
\hline & MDA-MB-435 & HCT-8 & SF-295 \\
\hline \multicolumn{4}{|c|}{ Stem bark of Tabebuia heptaphylla } \\
\hline$n$-hexane & 62.80 & 69.12 & 53.60 \\
\hline dichloromethane & 97.80 & 100.00 & 100.00 \\
\hline ethyl acetate & 59.72 & 100.00 & 98.00 \\
\hline$n$-butanol & 99.45 & 78.91 & 76.37 \\
\hline hydroalcohol & 89.87 & 61.19 & 48.65 \\
\hline \multicolumn{4}{|c|}{ Leaves of Tapirira guianensis } \\
\hline$n$-hexane & 46.51 & 48.14 & 49.17 \\
\hline dichloromethane & 86.13 & 88.00 & 79.67 \\
\hline ethyl acetate & 100.00 & 100.00 & 100.00 \\
\hline$n$-butanol & 97.36 & 99.88 & 100.00 \\
\hline hydroalcohol & 97.69 & 96.27 & 99.13 \\
\hline ethanol & 64.78 & 76.69 & 86.36 \\
\hline \multicolumn{4}{|c|}{ Stem bark of Tapirira guianensis } \\
\hline$n$-hexane & 77.11 & 77.11 & 77.11 \\
\hline dichloromethane & 36.72 & 36.72 & 36.72 \\
\hline ethyl acetate & 31.32 & 31.32 & 31.32 \\
\hline$n$-butanol & 37.93 & 37.93 & 37.93 \\
\hline hydroalcohol & 100.00 & 100.00 & 100.00 \\
\hline ethanol & 41.12 & 41.12 & 41.12 \\
\hline \multicolumn{4}{|c|}{ Heartwood of Myracrodruon urundeuva } \\
\hline ethanol & 95.60 & 95.60 & 95.60 \\
\hline \multicolumn{4}{|c|}{ Stem bark of Myracrodruon urundeuva } \\
\hline$n$-hexane & 94.28 & 49.42 & 60.12 \\
\hline dichloromethane & 99.45 & 58.75 & 56.21 \\
\hline ethyl acetate & 96.81 & 93.71 & 75.24 \\
\hline$n$-butanol & 94.28 & 100.00 & 94.27 \\
\hline hydroalcohol & 82.83 & 97.90 & 90.79 \\
\hline ethanol & 98.24 & 97.67 & 89.83 \\
\hline \multicolumn{4}{|c|}{ Leaves of Schinus terebinthifolius } \\
\hline$n$-hexane & 36.61 & 28.33 & 19.28 \\
\hline dichloromethane & 43.76 & 84.62 & 35.70 \\
\hline ethyl acetate & 94.83 & 97.44 & 100.00 \\
\hline$n$-butanol & 28.35 & 14.00 & 34.31 \\
\hline hydroalcohol & 30.38 & 54.14 & 27.27 \\
\hline \multicolumn{4}{|c|}{ leaves of Gomphrena elegans } \\
\hline$n$-hexane & 96.35 & 100.00 & 96.35 \\
\hline dichloromethane & 19.17 & 13.80 & 19.17 \\
\hline ethyl acetate & 10.04 & 0.91 & 10.04 \\
\hline$n$-butanol & 97.39 & 99.68 & 97.39 \\
\hline hydroalcohol & 10.43 & 18.24 & 10.43 \\
\hline \multicolumn{4}{|c|}{ Stem of Gomphrena elegans } \\
\hline$n$-hexane & 24.38 & 24.38 & 24.38 \\
\hline dichloromethane & 9.78 & 9.78 & 9.78 \\
\hline ethyl acetate & 16.43 & 16.43 & 16.43 \\
\hline$n$-butanol & 18.38 & 18.38 & 18.38 \\
\hline
\end{tabular}




\begin{tabular}{|c|c|c|c|}
\hline hydroalcohol & 19.95 & 19.95 & 19.95 \\
\hline \multicolumn{4}{|c|}{ Leaves of Attalea phalerata } \\
\hline$n$-hexane & 100.00 & 100.00 & 100.00 \\
\hline dichloromethane & 100.00 & 100.00 & 100.00 \\
\hline ethyl acetate & 94.72 & 81.35 & 65.77 \\
\hline$n$-butanol & 73.81 & 56.88 & 57.95 \\
\hline hydroalcohol & 100.00 & 100.00 & 100.00 \\
\hline \multicolumn{4}{|c|}{ Stem bark of Eugenia uniflora } \\
\hline ethanol & 95.60 & 84.85 & 75.24 \\
\hline \multicolumn{4}{|c|}{ Heattwood of Annona dioica } \\
\hline$n$-hexane & 43.19 & 35.74 & 52.87 \\
\hline chloroform & 100.00 & 95.63 & 100.00 \\
\hline methanol & 54.89 & 26.58 & 55.27 \\
\hline aqueous & 4.50 & 7.49 & 1.00 \\
\hline \multicolumn{4}{|c|}{ Stem bark of Annona dioica } \\
\hline$n$-hexane & 53.57 & 53.57 & 53.57 \\
\hline chloroform & 100.00 & 100.00 & 100.00 \\
\hline methanol & 4.76 & 4.76 & 4.76 \\
\hline aqueous & 3.64 & 3.64 & 3.64 \\
\hline \multicolumn{4}{|c|}{ Heartwood subterranean of Annona dioica } \\
\hline$n$-hexane & 63.29 & 58.59 & 47.93 \\
\hline chloroform & 100.00 & 100.00 & 100.00 \\
\hline methanol & 92.46 & 82.84 & 80.73 \\
\hline aqueous & 29.83 & 2.54 & 9.80 \\
\hline \multicolumn{4}{|c|}{ Stem bark subterranean of Annona dioica } \\
\hline$n$-hexane & 91.53 & 91.53 & 91.53 \\
\hline chloroform & 100.00 & 100.00 & 100.00 \\
\hline methanol & 38.69 & 38.69 & 38.69 \\
\hline aqueous & 29.23 & 29.23 & 29.23 \\
\hline \multicolumn{4}{|c|}{ Leaves of Annona dioica } \\
\hline$n$-hexane & 39.88 & 35.74 & 44.53 \\
\hline chloroform & 96.89 & 89.44 & 80.40 \\
\hline methanol & 36.38 & 41.60 & 38.33 \\
\hline aqueous & 13.89 & 10.33 & 11.93 \\
\hline
\end{tabular}

*Results are represented by means of three replicates.

(Hoehne, 1939; Pott \& Pott, 1994). Although we have not found any report on phytochemical analysis of the leaves and fruits, the isolation of the lignans cycloolivil and secoisolariciresinol, three lapachones, two naphthofuranes and one naphthalene derivative from the stem bark of this species have been reported previously (Schmeda-Hirschmanna \& Papastergiou, 2003). In the Bignoniaceae family, naphthoquinones is the principal group of secondary metabolites. There are reports dealing with the following activities for these compounds: antimalarial (Pérez et al., 1997), antitumor (Ueda et al., 1994), anticancer (Abbott et al., 1967), antifungal (Guiraud et al., 1988), antibacterial and anti-inflammatory (Zani et al., 1991). Among the naphthoquinones, studies performed with lapachol and beta-lapachone showed important in vitro antitumor activity and they were thus clinically tested by NCI (USA) (Da Silva et al., 2003).

Tapirira guianenses is popularly known as "tatapiririca" or "cedroí". People use different parts of the plant to treat diarrhoea and syphilis. The aqueous extract of the bark presents a uterus-stimulant effect (Correia et al., 2003). No published phytochemical study was found for this species.

In brazilian traditional medicine, Myracrodruon urundeuva has achieved popularity and a reputation. It is still largely used in the states of Mato Grosso do Sul and Mato Grosso by indigenous and riverside people. 
Properties such as anti-inflammatory and wound healing in gynecological illnesses are attributed to the plant. Its leaves are utilized to prepare plaster casts for broken bones, and as bactericidal and first-aid medicine for snake bites. In addition, the plant is also used as an antidiarrhoeic, astringent and antisyphilis (Martins et al., 2000). Souza et al. (2006) evaluated the antiinflammatory and antiulcer properties of the tanninenriched fraction isolated from the stem bark of $M$. urundeuva. They disclosed that these activities are partly due to its antioxidant action, known to be linked to the presence of polyphenols, including tannins (Morais et al., 2005). Botelho et al. (2007) examined the effect of topical herbal gel from Lippia sidoides $0.5 \%(\mathrm{v} / \mathrm{w})$ and M. urundeuva $5 \%(\mathrm{w} / \mathrm{w})$ in experimental periodontal disease in rats showing potential as a treatment for reducing tissue lesions (Souza et al., 2006). The chalcone dimers urundeuvina $\mathrm{A}$ and $\mathrm{B}$ were isolated from the inner bark of a specimen of $M$. urundeuva (Botelho et al., 2007) together with the antioxidant compounds cicloeucalenol and cicloeucalenona (Bandeira et al., 1994).

Fruits of Schinus terebinthifolius are spices used to increase flavor in food worldwide (Viana et al., 2003). In folk medicine, bark, leaves and fruits are used as antidiarrhoeic, astringent, anti-inflammatory, depurative, diuretic and febrifuge. The essential oils are used to treat respiratory distress (Ceruks et al., 2007). Moreover, triterpenes with an inhibitory effect on phospholipase A2 were isolated from the plant and its extracts showed antibacterial, antifungical and antiradicalar activities (Degáspari et al., 2005; Jain et al., 1995).

It is worth mentioning that species of Anacardiaceae family are known for presenting compounds with alkyl and alkenyl groups attached to catechol, resorcinol and phenol rings. These compounds, named as phenolic lipids, show nematicidal (Velászquez et al., 2003), antioxidant (Valcic et al., 2002), antifungical, and cytotoxic activities (Queiroz et al., 2003; Davis et al., 1997; Correia et al., 2001).

Some species from the Amaranthaceae family are being investigated for their varied biological properties. Antitumor activity against melanomas was detected in Pfaffia paniculata (Takemoto et al., 1983), and this property was accredited to the presence of anabolic agents such as $\beta$-ecdysterone and ecdysteroids glycoside. Phytochemical studies with in the genera Amaranthus account for the presence of saponins (Takemoto et al., 1983; Nishimoto et al., 1984; Oleszek et al., 1999), sapogenins (Escudero et al., 1998), rutin (Xaziev et al., 1992), steroids (Ologunde et al., 1992) and hydroxycinnamic esters of isocitric acid (Strack et al., 1987). Several works describe the antitumor activity of the genera Gomphrena, possibly associated to the production of saponins and phytoecdisteroids (Pomilio et al., 1994; Sarker et al., 1996; Young et al., 1997; Savchenko et al., 1998). Gomphrena elegans Mart. var. elegans is a herbaceous species frequently found in locations called "carandazais", "espinheirais" (thorn scrub), "vazantes" (drainage channels), ciliar vegetation, wetlands and clayed soil. Its distribution is restricted to tropical and subtropical South America as a hygrophytic plant in fields near rivers Sucuri and Baía Bonita (Bonito-MS) (Prance \& Schaller, 1982). No phytochemical study was found for this species.

The Palmae family has special economical and ecological importance. Millions of animal species make use of palm trees not only as a source of food, but also for protection and reproduction area (Vormisto et al., 2004). A considerable number of people in the tropics depend on these plants for their daily survival. Acuri (Attalea phalerata), coconut palm (Cocos nucifera), palm kernel (Elaeis guienensis), date palm (Phoenix dactyliphera), açai (Euterpe oleraceae), pejibaye (Bactris gasipaes), babassu (Attalea speciosa), piassava (Attalea funifera) and the carnauba (Copernicia prunifera) are some examples (Vormisto et al., 2004). The limited chemical studies of this plant family are focused on the investigation of Cocos nucifera biological activity. Alviano et al. (2004), detected analgesic and free radical scavenging properties in the aqueous extract of stem bark fibers. In addition, we also detected effects such as leishmanicide, antioxidant and antiviral (Mendonça et al., 2004; Kirszberg et al., 2003; Esquenazi et al., 2002) when analyzing the same extract. The Attalea phalerata (acuri) is a palm tree from the Pantanal region known as "acurizais" (Pott \& Pott, 1994). In some areas, the fruit seems to be a key source of energy for animals (Terborgh, 1986; Guedes \& Harper, 1995). It was selected because of its abundance and lack of available phytochemical data even though there is no literature register on popular medicinal use for this species.

Another promising source of bioactive compounds is the Annonaceaea family comprising about 120 genera and over 2.300 species. From a phytochemistry point of view, this family is worth studying due to several types of structural compounds classes that can be found such as: alkaloids, amides, diterpenes, steroids, flavonoids and acetogenins (Pontes et al., 2004). The use of Annonaceae plants in folk medicine has been widely reported associated with varied biological activities such as antimicrobial, antiemetic, pesticide, abortive, antitumor, cytotoxic, anorexic and antimalarial (Leboeuf et al., 1982). Many of these activities are assigned to acetogenins that have been a target of intense investigation in the last years (Rupprecht et al., 1990).

Therefore, as a part of our research program 
on bioactive plants native to the brazilian mid-west region, this study aimed to perform a preliminary investigation of not fully studied vegetal species extracts in order to obtain a scaffold for more detailed chemical analysis in the future.

The good results of cytotoxic activity in wild Tapirira guianensis, Attalea phalerata and Myracrodruon urundeuva front cell lines tested (MDA-MB-435, HCT-8 and SF-295); clearly indicate the importance of continuing phytochemical studies aimed at identify the active compounds present in extracts.

\section{Acknowledements}

We thank PROPP UFMS, FINEP and FUNDECT MS for scholarship and financial support. The authors are also in debt with all technicians of UFMS and UFC involved in this research.

\section{References}

Abbott BJ, Hartwell JL, Leiter J, Perdue RE JR, Schepartz SA 1967. Screening data from the cancer chemotherapy national service center screening laboratories. XL. Plant extracts. Cancer Res 27: 190-345.

Alviano DS, Rodrigues KF, Leitão SG, Rodrigues ML, Matheus ME, Fernandes PD, Antoniolli AR, Alviano CS 2004. Antinociceptive and free radical scavenging activities of Cocos nucifera L. (Palmae) husk fiber aqueous extract. $J$ Ethnopharmacol 92: 269-273.

Bandeira MAM, Matos FCA, Braz-Filho R 1994. New chalconoid dimers from Myracrodruon urundeuva. Nat Prod Res 4: 113-120.

Berridge MV, Tan AS, McCoy KD, Wang R 1996. The biochemical and cellular basis of cell proliferation assays that use tetrazolium salts. Biochemica 4: 1419.

Botelho MA, Rao VS, Carvalho CBM, Bezerra-Filho JG, Fonseca SGC, Vale ML, Montenegro D, Cunha F, Ribeiro RA, Brito GA 2007. Lippia sidoides and Myracrodruon urundeuva gel prevents alveolar bone resorption in experimental periondontitis in rats. $J$ Ethnopharmacol 113: 471-478.

Braz-Filho R 1999. Brazilian phytochemical diversity: bioorganic compounds produced by secondary metabolism as a source of new scientific development, varied industrial applications and to enhance human health and the quality of life. Pure Appl Chem 71: 1663-1972.

Cechinel Filho V, Yunes RA 1998. Estratégias para a obtenção de compostos farmacologicamente ativos a partir de plantas medicinais conceitos sobre modificação estrutural para otimização da atividade. Quim Nova 21: 99-105.
Ceruks M, Romoff P, Fávero AO, Lago JHGU 2007. Constituíntes fenólicos polares de Schinus terebinthifolius Raddi, Anacardiaceae. Quim Nova 30: 597-599.

Correia SJ, David JM, David JP, Chai HB, Pezzuto JM, Cordell GA 2001. Alkyl phenols and derivatives from Tapirira obtusa. Phytochemistry 56: 781-784.

Correia SJ, David JP, David JM 2003. Constituintes das cascas de Tapirira guianensis, Anacardiaceae. Quim Nova 26: 36-38.

Da Silva MN, Ferreira VF, De Souza MCBV 2003. An overview of the chemistry and pharmacology of naphthoquinones with emphasis on beta-lapachone and derivatives. Quim Nova 26: 407-416.

Davis RG, Whaler KA, Rivero-Cruz, JF, Chavez D, Hernandez BB, Anaya AL, Mata R 1997. Separation and characterization of Metopium brownei urushiol components. Phytochemistry 45: 1003-1008.

Degáspari CH, Waszczynskyj N, Prado MRM 2005. Atividade antimicrobiana de Schinus terebinthifolius Raddi. Cienc Agrotec 29: 617-622.

Escudero N, Mucciarelli S, Rossomando P 1998. Sapogenin from leaves of Amaranthus cruentus. Acta Farm Bonaer 17: 225-228.

Esquenazi D, Wigg MD, Miranda MMFS, Rodrigues HM, Tostes JBF, Rozental S, Da Silva A JR, Alviano CS 2002. Antimicrobial and antiviral activities of polyphenolics from Cocos nucifera Linn. (Palmae) husk fiber extract. Res Microbiol 153: 647-652.

Guedes NMR, Harper LH 1995. Hyacinth macaws in the Pantanal. In: Abramson J, Speer BL, Thomsen JB (eds.). The large macaws: their care, breeding and conservation. California: Raintree Publications, $\mathrm{p}$. 163-174.

Guiraud M, Kindack D, Dawson BA, Ethier JC, Awang DVC, Entry AH 1988. Naphtoquinone constituents of Tabebuia spp. J Nat Prod 51: 1023-1024.

Hoehne FC 1939. Plantas e substâncias vegetais tóxicas e medicinais. São Paulo: Graphicars.

Jain MK, Yu BZ, Rogers JM, Smith AE, Boger ET, Ostrander RL, Rheingold AL 1995. Specific competitive inhibitor of secreted phospholipase A2 from berries of Schinus terebinthifolius. Phytochemistry 39: 537-47.

Kirszberg C, Esquenazi D, Alviano CS, Rumjanek VM 2003. The effect of a catechin-rich extract of Cocos nucifera on lymphocytes proliferation. Phytother Res 17: 10541058.

Leboeuf M, Cavé A, Bhaumik PK, Mukerjee B, Mukherjee R 1982. The phytochemistry of the Annonaceae. Phytochemistry 21: 2783-2813.

Maciel MA, Pinto AC, Veiga-Júnior VF 2002. Plantas medicinais: a necessidade de estudos interdisciplinares. Quim Nova 25: 429-438.

Martins ER, De Castro DM, Castellani DC, Dias JE 2000. Plantas Medicinais. Viçosa: UFV. 
Mendonça RR, Rodrigues IA, Alviano DS, Santos, ALS, Soares RMA, Alviano CS, Lopes AHCS, Rosa MDSS 2004. Leishmanicidal activity of polyphenolic-rich extract from husk fiber of Cocos nucifera Linn. (Palmae). Res Microbiol 155: 136-143.

Morais SM, Dantas JDP, Silva ARA, Magalhães EF 2005. Plantas medicinais usadas pelos índios Tapebas do Ceará. Braz J Pharmacogn 15: 169-177.

Mosmann T 1983. Rapid colorimetric assay for cellular growth and survival: application to proliferation and cytotoxicity assays. J Immunol Methods 16: 55-63.

Nishimoto N, Nakai S, Takagi N, Hayashi S, Takemoto T, Odashima S, Kizu H, Wada Y 1984. Pfaffosides and nortriterpenoid saponins from Pfaffia paniculata. Phytochemistry 23: 139-42.

Nunes GP, Da Silva MF, Resende UM, De Siqueira JM 2003. Plantas medicinais comercializadas por raizeiros no centro de Campo Grande, Mato Grosso do Sul. Braz J Pharmacogn 13: 83-92.

Oleszek W, Junkuszew M, Stochmal A 1999. Determination and toxicity of saponins from Amaranthus cruentus seeds. J Agric Food Chem 47: 3685-3687.

Ologunde MO, Ayorinde FO, Shepard RL, Afolabi OA, Oke OL 1992. Sterols of seed oils of Vernonia galamensis, Amaranthus cruentus, Amaranthus caudatus, Amaranthus hybridus and Amaranthus hypochondriacus grown in the humid tropics. J Sci Food Agric 58: 221-225.

Pérez H, Diaz F, Medina JD 1997.Chemical investigation and in vitro antimalarial activity of Tabebuia ochracea ssp neochrysantha. Int J Pharmacol 35: 227-231.

Pomilio AB, Sola G, Mayer AMS, Rumi LS 1994. Antitumor and cytotoxic screen of 5,6,7-trisubstituted flavones from Gomphrena martiana. J Ethnopharmacol 44: 2533.

Pontes F, Barbosa MRV, Maas PJM 2004. Flora paraibana: Annonaceae Juss. Acta Bot Bras 18: 281-293.

Pott A, Pott VJ 1994. Plantas do pantanal. Campo Grande: Embrapa-CNPGC.

Prance GT, Schaller GB 1982. Preliminary study of some vegetation types of the Pantanal, Mato Grosso. Brazil. Brittonia 34: 228-251.

Queiroz EF, Kuhl C, Terreaux C, Mavi S, Hostettmann K 2003. New dihydroalkylhexenone from Lannea edulis. J Nat Prod 66: 578-580.

Rupprecht JK, Hui YH, MacLaughlin JL 1990. Annonaceous acetogenins: a review. J Nat Prod 3: 237-278.

Sarker SD, Girault JP, Lafont R, Dinan LN 1996. Ecdysteroids from Gomphrena haageana, Amaranthaceae. Biochem Syst Ecol 24: 177-178.

Savchenko T, Whiting P, Sarker SD, Dinan L 1998. Distribution and identity of phytoecdysteroids in Gomphrena spp., Amaranthaceae. Biochem Syst Ecol 26: 337-346.

Schmeda-Hirschmanna G, Papastergiou F 2003. Naphthoquinone derivatives and lignans from the paraguayan crude drug "Tayı"Pyta" (Tabebuia heptaphylla, Bignoniaceae). Z Naturforsch 58: 495501.

Skehan P, Storeng R, Scudiero D, Monks A, McMahon J, Vistica D, Warren JT, Bokesch H, Kenney S, Boyd MR 1990. New colorimetric cytotoxicity assay for anticancer-drug screening. J Natl Cancer Inst 82: 1107-1112.

Souza SMC, Aquino LCM, Milach Jr AC, Bandeira MAM, Nobre MEP, Viana GSB 2006. Antiinflammatory and antiulcer properties of tannins from Myracrodruon urundeuva Allemão, Anacardiaceae, in Rodents. Phytother Res 21: 220-225.

Strack D, Leicht P, Bokern M, Wray V, Grotjahn L 1987. Hydroxycinnamic acid esters of isocitric acid: accumulation and enzymatic synthesis in Amaranthus cruentus. Phytochemistry 26: 2919-2922.

Suffness M, Pezzuto JM 1990. Assays related to cancer drug discovery. In: Hostettmann K, (ed.). Methods in plant biochemistry: assays for bioactivity. London: Academic Press, p. 71-133.

Takemoto T, Nishimoto N, Nakai S, Takagi N, Hayashi S, Odashima S, Wada Y 1983. Pfaffic acid, a novel nortriterpene from Pfaffia paniculata Kuntze. Tetrahedron Lett 24: 1057-1060.

Terborgh J 1986. Keystone plant resources in the tropical forest. In: Soulé ME (ed.). Conservation biology: the science of scarcity and diversity. Sunderland: Sinauer, p. 330-344.

Ueda S, Umemura T, Dohguchi K, Matsuzaki T, Tokuda H, Nishino H, Iwashima A 1994. Production of antitumor-promoting furanonaphthoquinones in Tabebuia avellanedae cell-cultures. Phytochemistry 36: 323325

Valcic S, Wächter GA, Eppler CM, Timmermann BN 2002. Nematicidal alkylen resorcinols from Lithraea molloides. J Nat Prod 65: 1270-1273.

Velázquez E, Tournier HA, Buschiazzo PM, Saavedra G, Schinella GR 2003. Antioxidant activity of paraguayan plant extracts. Fitoterapia 74: 91-94.

Viana GSB, Bandeira MAM, Matos FJA 2003. Analgesic and antiinflammatory effects of chalcones isolated from Myracrodruon urundeuva Allemão. Phytomedicine 10: 189-195.

Vormisto J, Svenning JC, Hall P, Balslev H 2004. Diversity and dominance in palm (Arecaceae) communities in terra firme forests in the western Amazon basin. $J$ Ecol 92: 577-588.

Xaziev RS, Garusov AV, Oficherov EN 1992. Rutin concentration in Amaranthus cruentus L. grown in Tatarstan. Rastit Resur 28: 63-66.

Young MCM, Potomati A, Chu EP, Haraguchi M, Yamamoto M, Kawano T 1997. C-13 NMR analysis of monodesmosidic saponins from Gomphrena macrocephala. Phytochemistry 46: 1267-1270.

Zani CL, De Oliveira AB, De Oliveira GG 1991. Furanonaphthoquinones from Tabebuia ochracea. Phytochemistry 30: 2379-2381. 


\section{*Correspondence}

Talal Suleiman Mahmoud

Instituto de Química, Universidade Estadual Paulista

Rua Francisco Degni s/n, Caixa Postal 355, 14801-970

Araraquara-SP, Brazil

talalsuleiman@iq.unesp.br

Tel. +55 $6733453578 / 3676$

Fax +556733453552 